\title{
THE LIVED EXPERIENCES OF TEACHER AND STUDENTS IN PE AMIDST THE PANDEMIC
}

\author{
Ma. Isabel O. Mojica \\ Graduate School, Laguna State Polytechnic University Santa Cruz, Laguna, Philippines
}

Article DOI: https://doi.org/10.36713/epra7342

DOI No: 10.36713/epra7342

\begin{abstract}
Conducting classes remotely to shift in teaching paradigm of learning due to the on-going pandemic has posed many challenges to the education sector. Despite these efforts, several arguments are associated with remote learning especially with online classes or e-learning amidst the pandemic. The study aimed to unveil the lived experience of teachers and student who are taking remote learning in physical education subject. The respondents must had experience and engaging in remote learning.

This study employed both qualitative and quantitative methods of research. The respondents must had experience and engaging in remote learning. This study answered the following: What is the demographic profile of teachers and students? What are the challenges encountered by teachers and students? What are the coping mechanisms of teachers and students during remote learning? Is there a relationship between challenges encountered and coping mechanisms of teachers and students? How do the profile of the teachers and students relate to the challenges encountered and their coping mechanisms? For the qualitative part, an Interpretative Phenomenological Analysis (IPA) method was used to interpret the meanings of experiences of human life, and focused on research question "What it is like to experience remote teaching and learning in physical education amidst the pandemic?".

Considering the results of the study, it can be said that the major problems faced by both teachers and students are the poor internet connection. This hampers the communication between the two as well as the communication among students. This breeds to a series of problems that stem from the lack of connectivity. Moreover, the most common coping mechanisms employed by both groups are engaging into activities that will help them distress.

The recommendations in internet connectivity dilemma may address at the institutional level. Government may call upon the internet providers to supply an affordable and reliable internet connection whether it be data connectivity only or postpaid, University may broaden their student support by providing services such as counseling session for the student's mental health and also provide guidelines for conducting remote learning classes considering the coverage, the amount of course requirements, schedule of submissions, assessments that may both protect the students and teachers from having unnecessary workload that may result to stress and anxiety, more trainings and supports for professional development in teaching during remote learning among teachers.
\end{abstract}

KEYWORDS: Coping Mechanism, Amidst pandemic, Coping Challenges, Remote learning

\section{INTRODUCTION}

This shift in teaching paradigm of learning due to the on-going pandemic has posed many challenges to the education sector. Any decisions that will be made by educational institutions must at all times consider the protection of students, faculty members, academic staff, communities, societies, and the nation as a whole. Thus, various learning modalities were explored.
There are about 3.5 million tertiary-level students enrolled in approximately 2,400 higher education institutions (HEI). Thus these institutions, have explored many learning modalities considering the capacity of their students or the availability of the facilities needed for learning. To address the needs of students, these institutions have implemented proactive policies for the continuance of education despite the closure ( Joaquin, Biana, \& Dacela, 2020). These include conducting classes remotely. 


\section{EPRA International Journal of Research and Development (IJRD)}

HEIs have implemented various modes of remote learning such as synchronous or real time online classes, and asynchronous or delayed-time classes. Moreover, faculty members are now being taught the use of various learning management systems (LMS) as part of their preparation for online classes, trainings are also being held to equip faculty members with skills for synchronous and asynchronous classes such as use of platforms for video communications, and video recording and editing. Some are also being required to create course packs or modules that will be available for students who do not have access to the internet.

However, despite these efforts, several arguments are associated with remote learning especially with online classes or e-learning. According to Bao (2020), the sudden change in remote learning has caused challenges to faculty members such as lack of online teaching experience, early preparation, or support from educational technology teams. For students, accessibility, affordability, flexibility, learning pedagogy, and lifelong learning are arguments raised related to online pedagogy (Dhawan, 2020).

Given these challenges, it is very timely to conduct a study on the experiences of both teachers and students utilizing remote learning especially in higher educational institutions.

\section{OBJECTIVES}

This study determined the experiences of teacher and students during remote learning in higher education institutions in Cavite. Specifically, the study sought answers to the following questions:

1. What is the demographic profile of teachers and students of physical education?

1.1 Age;

1.2 Sex;

1.3 Civil status;

1.4 Tenure;

1.5 Monthly income;

2. What are the challenges encountered by teachers and students of physical education during remote learning?
2.1 Pedagogical
2.2 Technological
2.3 Social
2.4 Institution
2.5 Socio-economic

3. What are the coping mechanisms of teachers and students of physical education during remote learning?

3.1 Positive well-being

3.2 Time management

3.3 Openness to change

3.4 Per mentoring

3.5 Collaboration

3.6 Socio economic

4. Is there a relationship between challenges encountered and coping mechanisms of teachers and students of physical education?

5. How do the profile of the teachers and students relate to the challenges encountered and their coping mechanisms?

For the qualitative part, an Interpretative Phenomenological Analysis (IPA) method was used to interpret the meanings of experiences of human life, and focused on research question "what it is like to experience remote teaching and learning in physical education amidst the pandemic?".

\section{METHODOLOGY}

This study used both qualitative and quantitative research design. For the qualitative design, this study utilized the phenomenological perspective in understanding the lived experiences of both teachers of physical education and students taking physical education following the Interpretative Phenomenological Analysis (IPA). The IPA method aimed to describe, and interpret the meanings of experiences of human life, and focuses on research questions such as what it is like to experience a particular situation, in this case remote teaching and learning. The study will delved into the perceptions, perspectives, understandings, challenges and feelings as consciously experienced by students and teachers. For the qualitative design, following the Differentiated Instruction Theory and Anderson's Theory of Online Learning, the study utilized a survey questionnaire to determine the challenges and coping mechanisms employed both by the students and teachers. A set of challenges and coping mechanisms were identified based on literature. Teachers and students were then asked to evaluate how these variables apply to their experiences. 
SJIF Impact Factor 2021: 8.013| ISI I.F.Value:1.241| Journal DOI: 10.36713/epra2016 ISSN: 2455-7838(Online)

\section{EPRA International Journal of Research and Development (IJRD)}

Volume: 6 | Issue: 6 | June 2021

- Peer Reviewed Journal

\section{RESULT AND DISCUSSION}

This chapter discusses the findings of the study based on the research questions

\begin{tabular}{|c|c|c|c|}
\hline & Characteristics & Frequency & Percentage \\
\hline \multirow{4}{*}{ Age } & 18-20 years old & 5 & 27.8 \\
\hline & 21-23 years old & 12 & 66.7 \\
\hline & 24-26 years old & 1 & 5.6 \\
\hline & Total & $\underline{18}$ & $\underline{100}$ \\
\hline \multirow[t]{3}{*}{ Sex } & Male & 5 & 27.8 \\
\hline & Female & 13 & 72.2 \\
\hline & Total & 18 & 100 \\
\hline \multirow{6}{*}{ Monthly Family Income } & 10,000 and below & 3 & 16.7 \\
\hline & $10,001-15,000$ & 6 & 33.3 \\
\hline & $15,001-20,000$ & 5 & 27.8 \\
\hline & $20,001-25,000$ & 1 & 5.6 \\
\hline & 25,001 and above & 3 & 16.7 \\
\hline & Total & $\underline{18}$ & $\underline{100}$ \\
\hline
\end{tabular}

For Students a total 18 students from a selected state university in Cavite participated in the study. For the qualitative part, the following were found: among the students, majority are 21-23 years old and female. In terms of family income, students are distributed in different levels

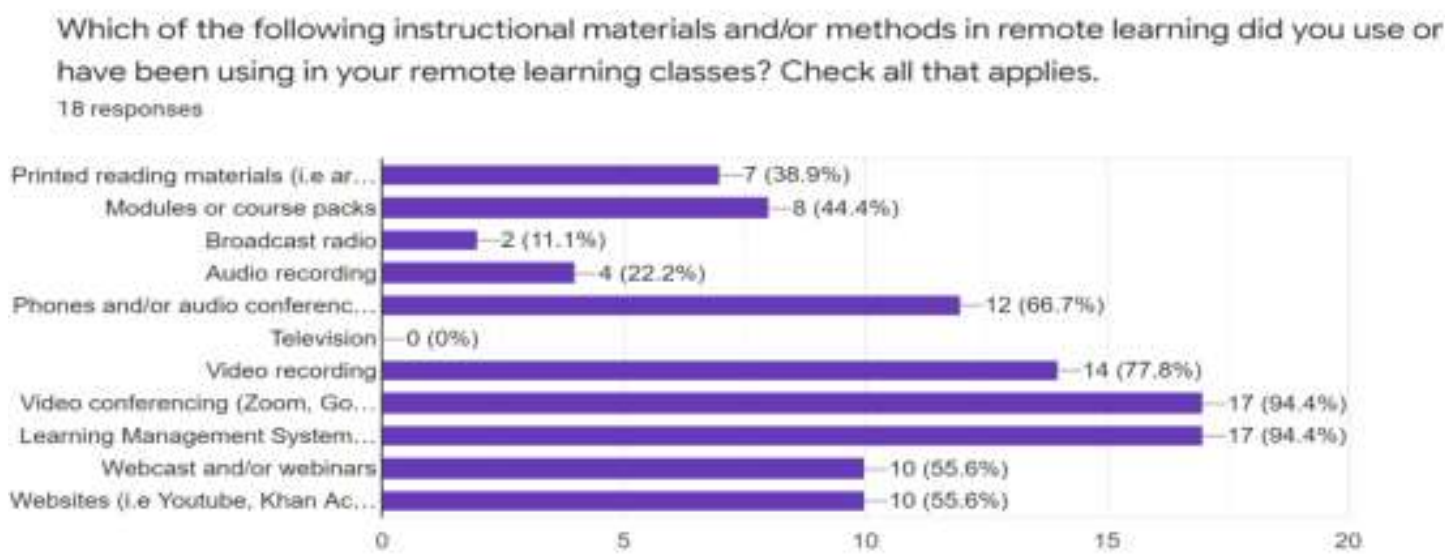

For remote learning modalities half of the respondents had experience engaging in remote learning before while the other half have experience them for the first time. Moreover, the two most often used learning modalities based on their experience are video conferencing and the use of learning management systems.

\begin{tabular}{|l|c|c|}
\hline Challenges & Mean & Verbal Interpretation \\
\hline Individual & 3.59 & Agree \\
\hline Technology & 2.39 & Disagree \\
\hline Institutional & 3.43 & Neutral \\
\hline Socio-economic & 3.83 & Agree \\
\hline Community & 3.59 & Agree \\
\hline
\end{tabular}




\section{EPRA International Journal of Research and Development (IJRD)}

In terms of challenges experienced during remote learning, mean score showed that they agree with the individual challenges, socio-economic challenges, and community challenges while they are neutral on institutional challenges. Surprisingly, they disagree on experiencing technological challenges based on the survey. However, during the interview, technology still appeared to be a problem. Yet, this time, it is mainly focused on poor internet connection unlike in the survey where it is a combination of infrastructure (devices), skills, and internet connectivity. Moreover, other challenges were identified during the interview. According to the students, they also face problems on mental health and heavy workload. Students feel stressed and anxious with everything they need to accomplish during remote learning with some having breakdowns. Heavy workload also adds to this pressure as they also have other responsibilities outside their remote learning class. Working students said that they often face problems on conflict of schedules with their synchronous classes and their work schedule. Also, not having an environment conducive for learning is also a problem as students said they have been distracted by many things such as human and pet intrusions.

\begin{tabular}{|l|c|c|}
\hline Coping Mechanisms & Mean & Verbal Interpretation \\
\hline Individual Well-being & 4.03 & Agree \\
\hline Time Management & 3.72 & Agree \\
\hline Socio-economic & 3.33 & Agree \\
\hline Peer Support & 3.96 & Agree \\
\hline Collaboration & 2.94 & Neutral \\
\hline
\end{tabular}

Considering the coping mechanisms they used to handle the challenges of remote learning, the students agreed to have been employing, individual wellbeing, time management, socio-economic and peer support related coping mechanisms as identified in the literature. They are on the other hand neutral with peer support. Further pondering on their experiences revealed, that they have been employing other mechanisms as well such as having family time as they see their family as source of stress relief. Another is engaging into recreational activities like sports, arts and watching movies. Students have identified time management to be a key in improving their experience with remote learning.
Considering challenges and coping mechanisms, a negative correlation was found between technological challenges and peer support. Since the students disagree that they are encountering technological challenges, the negative correlations mean the students does not need their peers for technological support. A positive correlation was also found between community challenges and socio-economic coping mechanisms which means that the mobility restrictions of the students affect their means to access connectivity and other resources needed in remote learning. No significant differences were found in terms of challenges and coping mechanism when students are grouped according to their demographic profile.

\begin{tabular}{|c|c|c|c|}
\hline & Characteristics & Frequency & Percent \\
\hline \multirow{5}{*}{ Age } & 25-30 years old & 6 & 35.3 \\
\hline & 31-35 years old & 6 & 35.3 \\
\hline & 36-40 years old & 4 & 23.5 \\
\hline & 46 years old and above & 1 & 5.9 \\
\hline & Total & 17 & 100.0 \\
\hline \multirow{3}{*}{ Sex } & Male & 11 & 64.7 \\
\hline & Female & 6 & 35.3 \\
\hline & Total & 17 & 100.0 \\
\hline \multirow{3}{*}{ Civil Status } & Single & 9 & 52.9 \\
\hline & Married & 8 & 47.1 \\
\hline & Total & 17 & 100.0 \\
\hline \multirow{4}{*}{ Tenure } & Job Order & 13 & 76.5 \\
\hline & Contractual & 2 & 11.8 \\
\hline & Permanent & 2 & 11.8 \\
\hline & Total & 17 & 100.0 \\
\hline
\end{tabular}




\section{EPRA International Journal of Research and Development (IJRD)}

Volume: 6 | Issue: 6 | June 2021

- Peer Reviewed Journal

For Teachers a total of 17 teachers from a selected state university in Cavite participated in the study. Their age is distributed in different age group while in terms of sex, majority are male. Moreover, majority of the teachers are on job order status while in terms of civil status, 9 were single and 8 were married. Majority of the teachers also said they have prior experience teaching remotely.

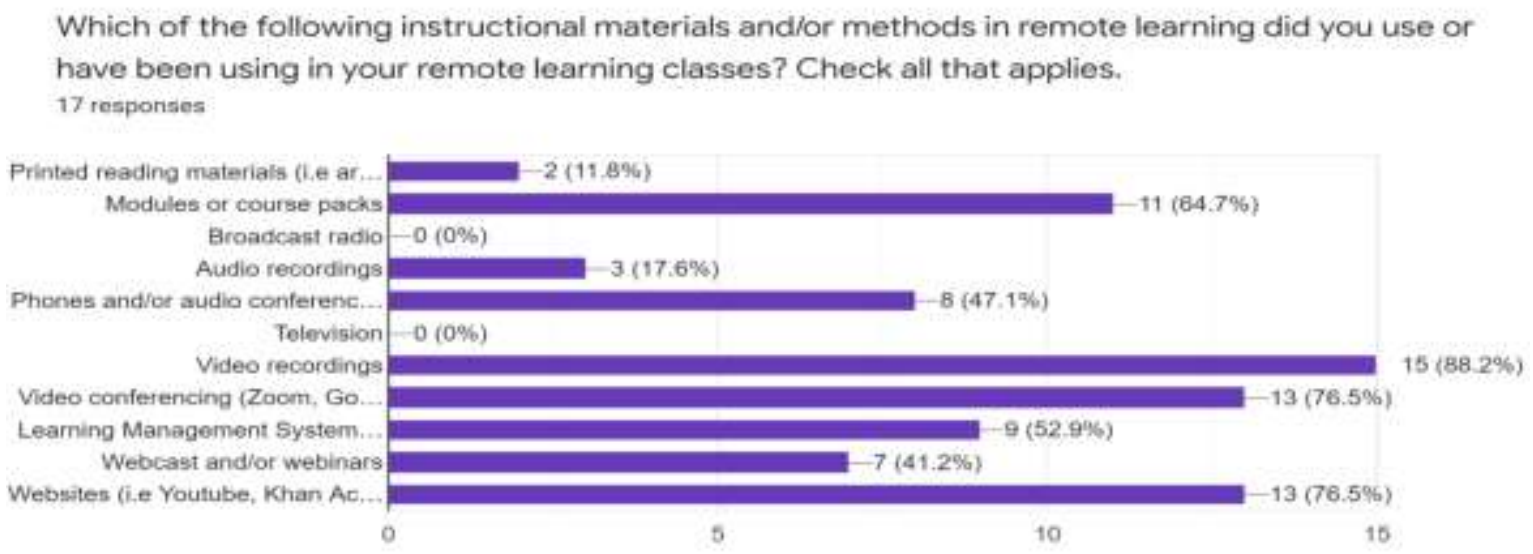

In terms of the learning modality used, the prefer video recording, followed by video conferencing, and utilization of platforms such as
YouTube. Modules are also popular among the teachers.

\begin{tabular}{|l|l|c|}
\hline Challenges & Mean & Verbal Interpretation \\
\hline Pedagogical & 1.96 & Disagree \\
\hline Technological & 1.88 & Disagree \\
\hline Social & 2.41 & Disagree \\
\hline Others & 2.32 & Disagree \\
\hline
\end{tabular}

In terms of the challenges experienced during remote learning, they all disagree with the predetermined variables. During the interview, the technological problem they experience are not on their part but on the side of the students. Hence, poor internet connection was one of the major theme in the interview. Another challenge identified are student related issues. According to them they have encountered numerous problems in terms of handling their students. From the students' failure to submit their requirements either because of lack of connectivity or them just being lazy, to being available to them all the time and having the need to be considerate despite instances where students tend to be apathetic and disrespectful. Another challenge that they face is related on their skills. According to them there is a need for them to upgrade their teaching methods by levelling up their skills like through video editing or using social medias. This is especially crucial because of the nature of PE which often demand instructional materials that shows demonstrations of activities.

\begin{tabular}{|l|c|c|}
\hline Coping Mechanisms & Mean & Verbal Interpretation \\
\hline Positive Well-being & 4.43 & Agree \\
\hline Time Management & 4.22 & Agree \\
\hline Openness To Change & 4.57 & Strongly Agree \\
\hline Peer Mentoring & 2.27 & Disagree \\
\hline Collaboration & 2.51 & Neutral \\
\hline
\end{tabular}

In terms of coping mechanisms, the teachers agreed with having a positive well-being, time management and openness to change as a coping mechanism while they disagree with peer mentoring and neutral with collaboration. The interview identified three coping mechanisms not mentioned in 
the survey, these are: engaging to sports, family time, and recreational activities. Based on the interview, most of the coping mechanisms identified were related in destressing.

In terms of relationship of challenges and coping mechanisms, there were several significant relationships found between pedagogical challenges and all of the coping mechanisms except time management. There were also significant relationships found between technology and positive well-being, peer mentoring and collaboration. Moreover, all the coping mechanisms were found to be significantly correlated with social challenges while other challenges were found to be significant with peer mentoring and collaboration. When grouped according to their demographic profile, no significant difference where found.

\section{CONCLUSION}

It was concluded therefore that the gap how students and teachers cope with remote learning within the Philippine context that is plagued by structural constraints and exacerbated by the current global crisis. Considering the results of the study, it could be said that the major problems faced by both teachers and students were the poor internet connection. This hampered the communication between the two as well as the communication among students. This breeded to a series of problems that stemed from the lack of connectivity. Moreover, the most common coping mechanism employed by both groups were engaging into activities that would help them destress.

\section{RECOMMENDATION}

Based on the findings and conclusion of the study, the following recommendations were offered.

1. The problem in internet connectivity may address at the institutional level. For instance, government may call upon the internet providers to supply an affordable and reliable internet connection whether it be data connectivity only or postpaid. Singapore for example has a cheaper prepaid data bundle and at the same time with quality level of connection.

2. The university may broaden their student support by providing services such as counseling to protect student's mental health. These services may also be accessible despite being remote and may protect their privacy.

3. The university may provide guidelines for conducting remote learning classes considering the coverage, the amount of course requirements, schedule of submissions, assessments, etc. that may both protect the students and teachers from having unnecessary workload that may result to stress and anxiety.

4. The university may provide more trainings and supports for professional development in teaching during remote learning among teachers. The same may also be provided to students to let them be familiar with the infrastructure needed in remote learning such as familiarization with the learning management systems.

\section{REFERENCES}

1. Adedoyin, O., \& Soykan, E. (2020). Covid-19 pandemic and online learning: the challenges and opportunities. Interactive Learning Environments .

2. Aksoy, Y., Çankaya, S., \& Taşmektepligil, $Y$. (2017). The Effects of Participating in Recreational Activities on Quality of Life and Job Satisfaction. Universal Journal of Educational Research, 5(6): 1051-1058.

3. Alase, A. (2017). The Interpretative Phenomenological Analysis (IPA): A Guide to a Good Qualitative Research Approach. International Journal of Education and Literacy Studies.

4. Alipio, M. (2020). Education during COVID-19 era: Are learners in a. $Z B W-$ Leibniz Information Centre.

5. Allen, J., Rowan, L., \& Singh, P. (2020). Teaching and teacher education in the time of COVID-19. Asia-Pacific Journal of Teacher Education.

6. Arenas, D., Viduani, A., Bassols, A., \& Hauck, S. (2021). Peer support intervention as a tool to address college students' mental health amidst the COVID-19 pandemic. International Journal of Social Psychiatry.

7. Bao, W. (2020). COVID -19 and online teaching in higher education: A case study of Peking University. Human Behavior and Emerging Technologies, 2(2), 113-115.

8. Besser, A. F.-H. (2020). Adaptability to a sudden transition to online learning during the COVID19 pandemic: Understanding the challenges for students. Scholarship of Teaching and Learning in Psychology.

9. Burns, M. (2011). Distance Education for Teacher Training: Modes, Models, and Methods. Education Development Center, Inc.

10. Chandra, Y. (2020). Online education during COVID-19: perception of academic stress and emotional intelligence, coping strateging among college students. Emerald Insight.

11. Choi , M., Tessler, H., \& Kao, G. (2020). Arts and crafts as an educational strategy and coping mechanism for Republic of Korea and United States parents during the COVID-19 pandemic. International Review of Education , 66, 715-735.

12. Coman, C., Mesesan-Schmitz, L., Tiru, L., \& Stanciu, C. (2020). Online Teaching and Learning in Higher Education during the Coronavirus Pandemic: Student Perspective. 


\section{EPRA International Journal of Research and Development (IJRD)}

Sustainability.

13. Cox, A., Solomon, B., \& Parris, D. (2018). Teacher well-being is a critical and often overlooked part of school health. Children Trends,

https://www.childtrends.org/blog/teacher-wellbeing-is-a-critical-and-often-overlooked-part-ofschool-health

14. Daniel, J. (2020). Education and the COVID-19 pandemic. UNESCO IBE. Springer.

15. Daum, D., \& Buschner, C. (2012). The Status of High School Online Physical Education in the United States. Journal of Teaching in Physical Education, 86-100.

16. De Villa, J., \& Manalo, F. (2020). Secondary Teachers' Preparation, Challenges, and Coping Mechanisms in the Pre-implementation of Distance Learning in the New Normal. IOER International Multidisciplinary Research Journal , 2(3).

17. Dhawan, S. (2020). Online Learning: A Panacea in the Time of COVID-19 Crisis. Journal of Educational Technology Systems.

18. Ferri , F., Grifoni , P., \& Guzzo, T. (2020). Online Learning and Emergency Remote Teaching: Opportunities and Challenges in Emergency Situations. Societies.

19. Jeong , H.-C., \& So, W.-Y. (2020). International Journal of Environmental Research and Public Health.

20. Jimena, G.-R., Mulqueen, K., Zealand, R., Silverstein, S., Mulqueen, C., \& BuShell, S. (2021). Emergency Online Learning: College Students' Perceptions During the COVID-19 Pandemic. College Student Journal.

21. Kebritchi, M., Santiague, L., \& Lipschuetz, A. (2017). Issues and Challenges for Teaching Successful Online. Journal of Educational Technology Systems.

22. Kelly, M. (2020). Largest COVID-19 contact tracing study to date finds children key to spread, evidence of superspreaders. Princeton Environmental Institute, https://www.princeton.edu/news/2020/09/30/larg est-covid-19-contact-tracing-study-date-findschildren-key-spread-evidence.

23. Khan, H., Farooqi, M., Khalil, A., \& Faisal, I. (2016). Exploring Relationship of Time Management with Teachers' Performance. Bulletin of Education and Research, 38 (2) pp. 249-263.

24. Klapproth, F. F. (2020). Teachers' experiences of stress and their coping strategies during COVID-19 induced distance teaching . Journal of Pedagogical Research, 4(4), 444-452.

25. Kohl, H., \& Cook, H. (2013). Educating the Student Body: Taking Physical Activity and Physical Education to School. (C. o. Environment, F. a. Board, \& I. o. Medicine, Eds.) Washington, DC: National Academies Press (US).

26. Lee, K.-H., Na, G., Song, C.-G., \& Jung, H.-Y. (2020). How Does Pedagogical Flexibility in Curriculum Use Promote Mathematical
Flexibility? An Exploratory Case Study. Mathematics, www.mdpi.com/journal/mathematics.

27. Li, C., \& Lalani, F. (2020). The COVID-19 pandemic has changed education forever. World Economic Forum, https://www.weforum.org/agenda/2020/04/coron avirus-education-global-covid19-online-digitallearning/.

28. Mahyoob, M. (2020). Challenges of e-Learning during the COVID-19 Pandemic Experienced by EFL Learners. Arab World English Journal (AWEJ).

29. Miller, K. (2020). 7 Time Management Tips for Online Students. Northeastern University Graduate Program, https://www.northeastern.edu/graduate/blog/time -management-tips-onlinestudents/\#: : text=One\%20of\%20the\%20most\%2 Ovaluable, is\%20to\%20achieve\%20your\%20goal s.\&text $=$ Effective $\% 20$ time $\% 20$ management $\% 20$ n ot\%20only, and\%20in\%20your\%20personal $\% 20 l$ ife.

30. Mishraa, L., Guptab, T., \& Shreeb, A. (2020). Online teaching-learning in higher education during lockdown period of COVID-19 pandemic. International Journal of Educational Research.

31. Montgomery, A. (2016). Recreational Participation and Perceived Stress Levels of College Students. Winthrop University.

32. Motz, B. A., Quick, J. D., Wernert, J. A., \& Miles, T. A. (2021). A Pandemic of Busywork: Increased Online Coursework Following the Transition to Remote Instruction Is Associated with Reduced Academic Achievement. Online Learning.

33. Niemi, H., \& Kousa, P. (2020). A Case Study of Students' and Teachers' Perceptions in a Finnish High School during the COVID Pandemic. International journal of technology in education and science.

34. Poth, R. D. (2019). The Importance of Being a Mentor and Having a Mentor. Getting Smart, https://www.gettingsmart.com/2019/02/theimportance-of-being-a-mentor-and-having-amentor/.

35. Rasheed, F., \& Wahid, A. (2018). THE THEORY OF DIFFERENTIATED INSTRUCTION AND ITS APPLICABILITY: AN E-LEARNING PERSPECTIVE. https://www.researchgate.net/.

36. Rotas, E., \& Cahapay, M. (2021). From stress to success: Exploring how Filipino students cope with remote learning amid COVID-19 pandemic. Journal of Pedagogical Sociology and Psychology, 3(1).

37. Rotas, E., \& Cahapay, M. (2021). From stress to success: Exploring how Filipino students. Journal of Pedagogical Sociology and Psychology.

38. Smith, J., \& Osborn, M. (2015). Interpretative phenomenological analysis as a useful methodology for research on the lived experience of pain. British Journal of Pain, 9(1), 41-42.

39. Stelitano, , L., Sy , D., Woo, A., Diliberti, M., Kaufman, J., \& Henry, D. (2020). The Digital 
Divide and COVID-19: Teachers' Perceptions of Inequities in Students' Internet Access and Participation in Remote Learning. Insights from the American Educator Panels.

40. The Department of Local Government, S. a. (2021). The relationship between organised recreational activity and mental health.

41. Thoma, P., Liu, H., \& Umberson, D. (2017). Family Relationships and Well-Being. Innovation in Aging, 1(3): igx025.

42. Tomlinson, C. A. (2000). Differentiation of Instruction in the Elementary Grades. ERIC Digest. ERIC Clearinghouse on Elementary and Early Childhood Education.

43. Tria, J. (2020). The COVID-19 Pandemic through the Lens of Education in the Philippines: The New Normal. International Journal of Pedagogical Development and Lifelong Learning.

44. Williams, L. (2013). A Case Study of Virtual Physical Education Teachers' Experiences in and Perspectives of Online Teaching. Retrieved from University of South Florida.

45. Yu, L., Shek, D., \& Zhu, X. (2018). The Influence of Personal Well-Being on Learning Achievement in University Students Over Time: Mediating or Moderating Effects of Internal and External University Engagement. Front. Psychol., 8:2287. doi: 10.3389/fpsyg.2017.02287.

46. Zote, J. (2020). Making Sense of the Different Types of Remote Learning. Wyzant, https://www.wyzant.com/blog/types-of-remotelearning/. 